\title{
Accounting
}

\section{The effect of financial distress on stock returns, through systematic risk and profitability as mediator variables}

\author{
Mulyanto Nugroho ${ }^{a^{*}}$, Donny Arif ${ }^{\mathrm{b}}$ and Abdul Halik ${ }^{\mathrm{a}}$
}

${ }^{a}$ Universitas 17 Agustus 1945 Surabaya, Indonesia

${ }^{b}$ Universitas Maarif Hasyim Latif, Indonesia

\section{H R O N I C L E}

\section{Article history:}

Received: January 24, 2021

Received in revised format:

April 252021

Accepted: April 27, 2021

Available online:

April 27, 2021

\section{Keywords:}

Financial Distress

Stock Returns

Systematic Risk

Profitability

\section{A B S T R A C T}

This study aims to determine the relationship between financial distress and systematic risk, the relationship between financial distress and profitability, the relationship between systematic risk and stock returns, the relationship between profitability and stock returns, and the indirect effect between financial distress and stock returns through systematic risk and company profitability. by collecting data on the Indonesia Stock Exchange on chemical companies and the element industry in 20182020. This study was conducted to find out the answers to the impact caused by the global economic turmoil. Using the PLS-SEM method and four latent variables, which are divided into one endogenous variable, two moderating variables and one exogenous variable, it is hoped that it can provide value for the statistical calculation activities carried out. This study uses a quantitative descriptive method with two moderating variables that link financial distress and stock returns. This study produces a specific indirect effect; the financial distress variable significantly impacts Stock Return through systematic risk and profitability variables with a $p$-value $<0.05$. The main finding of this study is the significant impact of world economic turmoil that must be faced by creating systematic risk to convince. Investors and provide education to potential investors.

\section{Introduction}

The company is an organization that mainly carries out economic activities carried out continuously and has a specific purpose. The company's main objective is to reduce systematic risk and increase the company's shares from good financial performance with the increased prosperity of owners or shareholders. For the development of economic conditions in the world and the state of economic actors will always experience ups and downs and will not always go well. When the crisis starts to hit, then many companies will share financial distress. Due to the company's declining economic and financial conditions, financial pain experienced by the company resulted in an increased risk of bankruptcy. On the other hand, the debate about the determining factors of financial distress sparked the interest of researchers decades ago, especially after the onset of the last financial crisis due to the significant consequences for all stakeholders of a company (Bravo-Urquiza \& Moreno-Ureba, 2021). The theory (Chen et al., 2018) explains that highly leveraged companies have a significant potential risk of bankruptcy that requires systematic risk handling to prevent them. Investors' purpose is to maximize the profit (Return)without forgetting the risky factors investment that must be faced. Return is one of the factors that motivate investors to invest and is in Return for the courage of

* Corresponding author.

E-mail address: nugroho@untag-sby.ac.id (M. Nugroho) 
investors to bear the risk of their investments. With any obstacles the world economy faces today, a variety of suitable handling methods can be overcome. Governance is less common among many companies, as it relies solely on soft information and does not get accurate and robust data to predict the possibility of future bankruptcies (Li et al., 2020). Investors also want assurances on the company's financial performance in the face of global economic challenges. The expected capital of the company is obtained from investors who need a return on their shares with maximum Return. Investors' purpose is to maximize profits (Return)without forgetting the investment risk factors that must be faced. Recovery is one of the factors that motivate investors to invest and is in Return for the courage of investors to bear the risk of their investments. The reaction to the capital market will be different during the recent financial crisis, as investors tend to avoid trouble. There is a decrease in the amount of capital issued by investors (Elyasiani et al., 2014). Therefore, the primary purpose of this study is to find out how likely it is to occur in the company's financial performance in the face of crises and unstable economic cycles, as well as the best way to convince investors of a systematic risk management plan to deal with it so that investors get a maximum return from the company's sound financial performance. Positive changes, and market demand increases, then systematic risk will decrease.

Conversely, if market demand decreases, either due to Systematic competition or changes in general economic conditions, investors' risk factors will increase significantly. When the company's risk factors are considered to increase due to outside factors beyond the company's control, attracting new investors is minimal. Our Analysis illustrates that during the covid-19 virus pandemic, there were many impacts on the entire world economy, including Indonesia, which experienced a gross domestic product (GDP) slump in the second quarter of 2020. From an economic point of view, it can be a lesson that systematic risk of returning shares to investors can be a shield in anticipation of similar events in the future.

\section{Literature Review}

\subsection{Financial distress on systematic risk}

Financial distress risk refers to the company's inability to meet its fixed monetary payment obligations to employees and shareholders (Gilson, 1989). In principle, the opposite of the risk of financial difficulties is that innovation requires large amounts of investment and generates uncertain returns; imitation strategies can become more expensive and make companies late to be competitive. The study (Mangena et al., 2020) explained that the role of banks becomes very central in helping financial difficulties in Spanish companies; banks provide debt and equity financing to the same companies. Some research (Salloum et al., 2013; Fich \& Slezak, 2008; (Hsu \& Wu, 2014) financial distress to systematic risks through the board of directors. The role of independent or outside directors has been gaining considerable attention over the years as they are believed to strengthen the company's financial performance and reduce the risk of bankruptcy due to external turmoil. Measures of financial difficulty with systematic risks carried out by the government are usually triggered by banks that massively sell their assets to restore optimal leverage after a shock. Also, small-scale regulation requires financial institutions to adjust capital to risk-based portfolio levels. They are also forced to rebalance the portfolio to safer assets to comply with regulations (Cifuentes et al., 2005; Cont \& Wagalath, 2016). There are not many studies investigating the relationship between corporate financial pressures and systematic risk measures, but (Benoit et al., 2012; 2017) show measurements that systematic global risks are theoretically and empirically related to market risk measurements and company characteristics. From the literature described above can be drawn the hypothesis that:

$\mathbf{H}_{1}$ : Financial Distress has a significant and significant effect on systematic risks in the primary and chemical industry sector on the Indonesia stock exchange for the period 2018-2020.

\subsection{Profitability}

Profitability Ratio can measure the company's ability to earn a profit, both about sales, assets, and capital itself (Nugroho et al., 2021). According to Nugroho et al. (2021), Profitability Ratio is a ratio that measures the company's ability to generate profit during a specific period and also provides an overview of the effectiveness of management in carrying out its operations. Profitability also has a positive relationship with the dividend payout ratio because the higher the level of profitability, the greater the dividend distributed by the company to investors.

$\mathbf{H}_{2}$ : Financial Distress has a significant and significant effect on profitability in the primary and chemical industry sector on the Indonesia stock exchange for the period 2018-2020.

\subsection{Systematic Risk to Stock Return}

An analysis of $\mathrm{Xu}$ (2021) based on impulse responses states that the increase in cases of covid-19 undermines the Return of existing shares in The Chest. From that Analysis, we reanalyzed what happened to the Indonesian economy caused by covid-19 with financial distress in all companies going public. For example, Ashraf (2020) found the stock market reacted negatively to the growth of COVID-19 cases based on panel data (Ashraf, 2020). To balance this, concrete steps are required for the severe handling of each stakeholder. At the same time Rong et al. (2020) suggest that good labor mobility will increase the company's 
value against the Return of shares. This indicates that internal patterns also affect the company's financial performance in obtaining maximum profit. The company's resilience in the face of the current negatively confirmed world economic turmoil in history has been stated like this (Mitton \& Vorkink, 2008). Based on the utility model shows investors have the option to determine, (Barberis \& Huang, 2008) explains the consequences of financial distress, assets that are considered positively skewed will get low returns. From the literature described above can be drawn the hypothesis that:

$\mathbf{H}_{3}$ : Systematic Risk has an effect and significant effect on the Return of Shares in the primary and chemical industry sector on the Indonesia stock exchange for the period 2018-2020.

\subsection{Profitability Against Stock Return}

According to Dyah and Mulyo (2012), there is an increase in the Return of shares in the company listed in the research list, assuming variable ROA, NPM, EPS, and PER have not changed. For variable ROA does not have a positive and insignificant influence on the Return of shares. Simultaneously, in NPM, there are positive and negligible to the Return of claims, and EPS and PER have a positive and significant influence on the Return of shares of manufacturing companies in the Food and Beverages sector. (Nugroho et al., 2020)states that together financial performance as measured by EPS, ROE, and DER has a significant effect on stock returns, but based on partial testing of financial performance variables as measured by EPS, ROE, and DER, respectively has no significant impact on stock returns. (Arif et al., 2020)entitled Analysis of the influence of DER, CR, and ROE on the Return of Shares (Study on Stock Index LQ45 Period 2009 - 2011 and Investors registered with 12 Securities Companies in Semarang Region Period 2012). T-test results on secondary data show that ROE variables have a significant adverse effect on Stock Return

H4: Profitability has an effect and significant effect on the Return of Shares in the primary and chemical industry sector on the Indonesia stock exchange for the period 2018-2020.

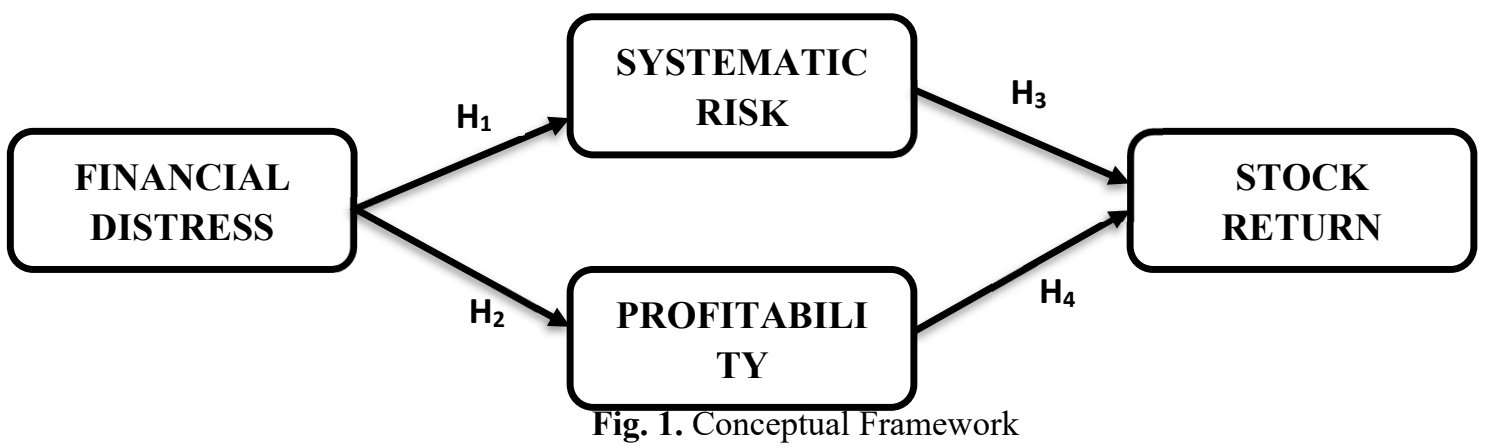

\section{Research Methodology}

This research uses quantitative research with a descriptive approach to finding out the relationship of financial distress with systematic risk and stock return and using secondary data in the form of financial report documentation released by the Indonesia Stock Exchange on companies in the primary industrial \& chemical sector. The population of this research is companies listed in the primary industrial \& chemical industry on the Indonesia Stock Exchange as of 2020 20, which amounts to 80 companies. Research samples used in this study in the form of purposive sampling techniques. By criteria:

1. Primary industrial \& chemical sector manufacturing companies listed on the Indonesia Stock Exchange as of 2020.

2. Primary industrial \& chemical sector manufacturing companies that reported consecutive financial statements during the period 2018-2020. This criterion is included because some companies have not published or published annual financial statements in 2020

3. Primary industrial \& chemical sector manufacturing companies experienced financial Distress with Zmijewski model analysis in 2018-2020.

\subsection{Data Collection Techniques}

The data collection techniques used are documentation and literature studies. This method collects data from the annual report on the Indonesia Stock Exchange period 2018-2020. According to Yucha (2018), the most accurate financial distress prediction analysis results are the Zmijewski models compared to Altman and Springate models. The study results by Grice and Dugan 
(2003) showed that the widespread application of the Zmijewski model currently poses problems with the validity of the construct, so that in this study will be taken in more detail using data in recent years from the Indonesia Stock Exchange.

This study used the Zmijewski model as an indicator of financial distress variables. The formula Zmijewski (X-Score) is described as follows:

$$
X=-4,3-4.5 X 1+5,7 X 2-0,004 X 3
$$

Description:

$\mathrm{X}_{1}=$ Earnings After Tax to Total Assets (ROA)

$\mathrm{X}_{2}=$ Total Debt to Total Assets (Debt to Asset Ratio)

$\mathrm{X}_{3}=$ Current Assets to Current Liabilities (Current Ratio)

\subsection{PLS-SEM Data Analysis}

We use the Partial Least Square (PLS-SEM) analysis, model. Partial least square structural equation modelling (PLS-SEM) is a next-generation analysis technique that has become a widespread concern in management science, marketing, information systems, finance and other social sciences, with an increasing number of studies at exponential levels in the last two decades (Hair et al., 2013). By drawing up a path diagram, this step shows the causality relationship of the construct. In this study, there are three indicators of construct variables in financial distress: ROA, Debt to Asset Ratio and Current Ratio, and three endogenous constructs: systematic Risk, profitability and Return of shares.

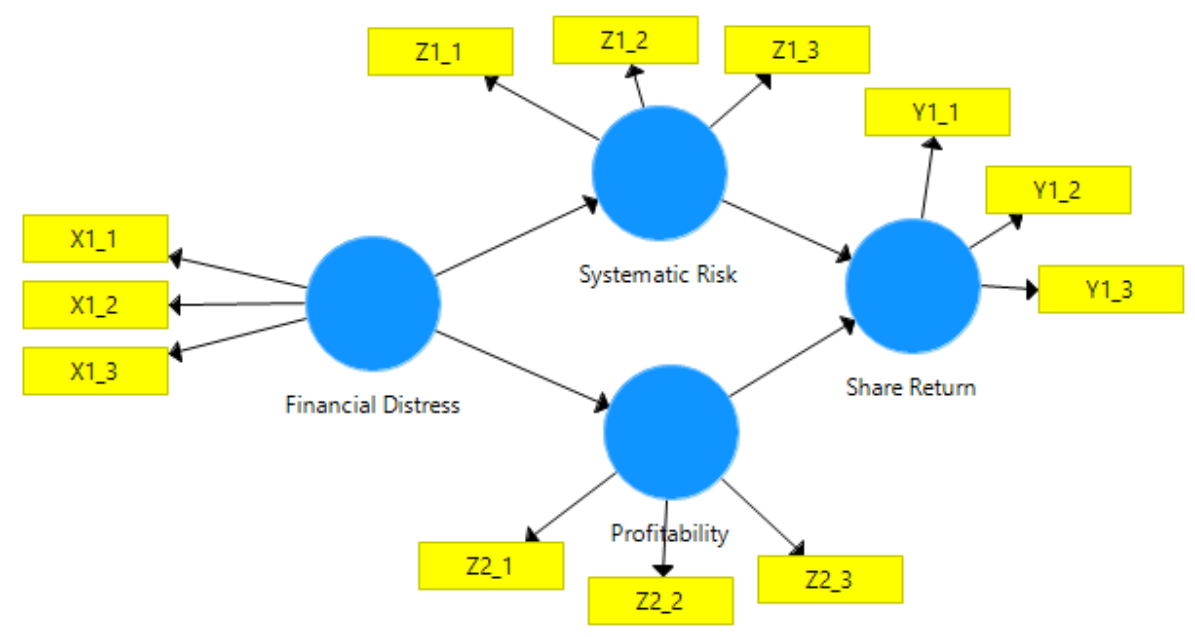

Fig. 2. Structure of PLS-SEM

Description:

$\mathrm{X} 1 \_1=$ ROA Indicator for Financial Distress

$\mathrm{X} 1 \_2=$ Debt to Asset Ratio Indicator for Financial Distress

$\mathrm{X} 1 \_3=$ Current Ratio Indicator for Financial Distress

Z1_1 = Exchange Rate Indicator for Systematic Risk

Z1_2 = Interest Indicator for Systematic Risk

Z1_3 = Inflation Indicator for Systematic Risk
Z2_1 = NPM Indicator for Profitability

$\mathrm{Z} 2 \_2=\mathrm{ROA}$ Indicator for Profitability

$\mathrm{Z} 2$ _3 = Indicator ROE for Profitability

Y1_1 = Indicator DPR for Stock Return

Y1_2 = Indicator PHS for Stock Return

Y1_3 = Indicator PVS for Stock Return

\section{Research Results}

Before conducting the hypothesis test to determine the value of the latent variable structures, testing is required to verify the indicators in latent variables, including testing the validity of the construct (convergent validity and discriminant validity) and the reliability of the construct. The model results of the test image are as follows,

1. Financial distress has three indicators for ROA, Debt Payment Ratio and Current Ratio. Of these three indicators, each has a loading factor value, namely: ROA with loading factor 0. 928, Debt Payment with loading factor 0.978 and Current Ratio with loading factor -0.969 . By the minimum value of convergent validity is $>0.5$, the indicator of Financial Distress has complied, and there is no need to drop. 
2. Systematic risk has three indicators for the exchange rate, interest and inflation. Each has a loading factor value of these three indicators: exchange rate with loading factor -0.972 , interest with loading factor 0.984 and inflation with loading factor 0.967 . By the minimum value of convergent validity is $>0.5$, the indicator of Financial Distress has complied, and there is no need to drop.

3. Profitability has three indicators for NPM, ROA and ROA. From these three indicators, each has a loading factor value, namely: NPM with loading factor 0. 930, ROA with loading factor 0.996 and ROE with loading factor 0.997. By the minimum value of convergent validity is $>0.5$, the indicator of Financial Distress has complied, and there is no need to drop.

4. Stock Return has three indicators. Also, yes, it's DPR, PHS and PVS. Of these three indicators, each has a loading factor value, namely: DPR with loading factor 0. 945, PHS with loading factor 0. 357 and PVS with loading factor -0.094. The minimum value of convergent validity is $>0,5$, the indicator of Systematic Risk only one that meets the criteria of value more than the minimum limit of convergent validity, so it needs to be dropped.

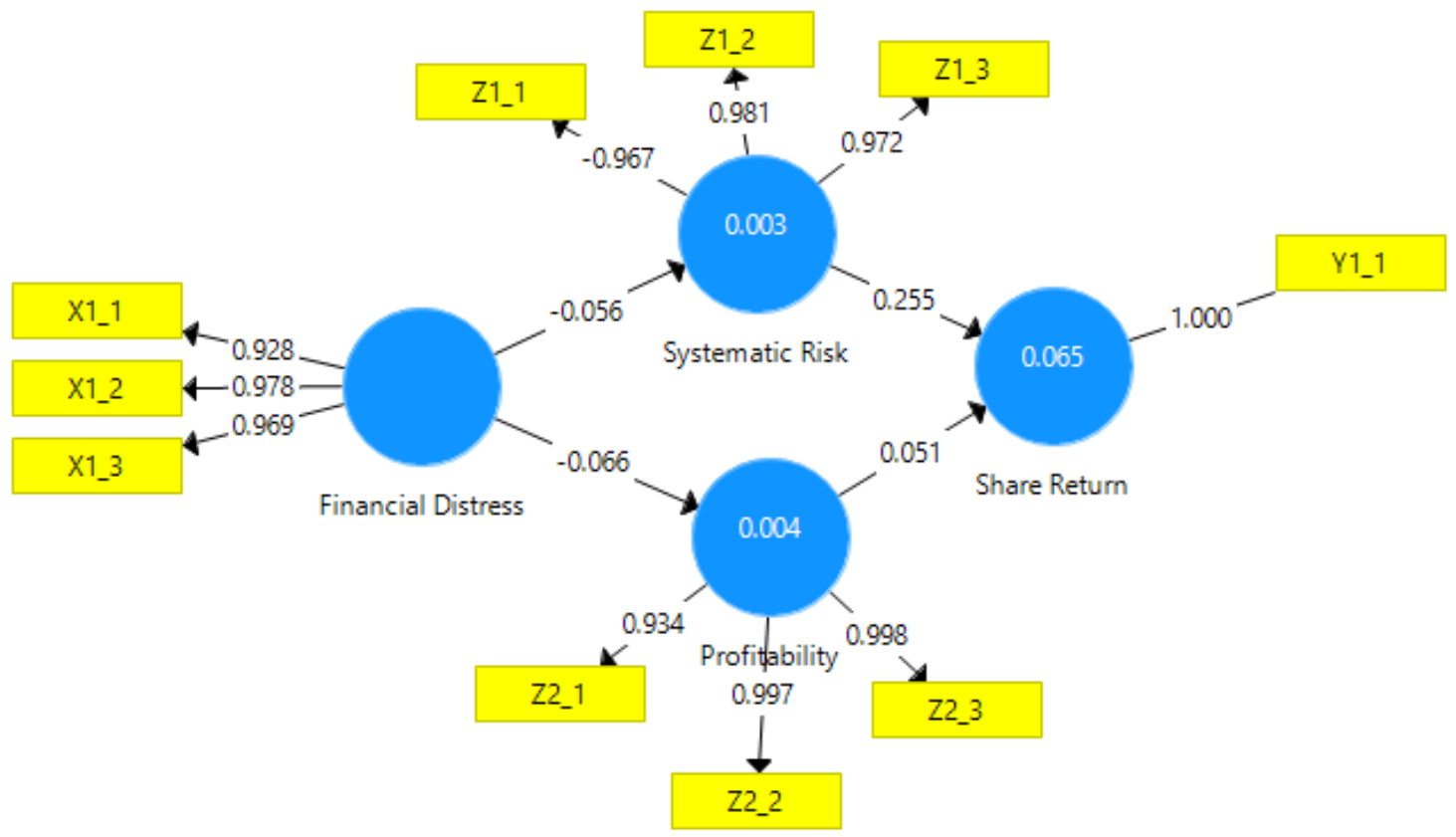

\section{Discussion}

Fig. 3. Outer Model Calculation Results After Dropping

In hypothesis testing, the value analyzed is the value present in the $t$-statistic generated from the PLS output by comparing it with the t-table value. Pls output is a latent variable estimate which is the aggregate linear of the indicator. The hypotheses used are as follows:

Testing criteria with a significance rate $(\alpha)$ of $5 \%$ are determined as follows:

1. If the $t$-count $>t$ table is more than 1.66, then the hypothesis is accepted.

2. If $t$ count $<t$ table, that is less than 1. 66, then the hypothesis is rejected.

\section{Table 1}

Output Bootstrapping-PLS

\begin{tabular}{lcc}
\hline & T Statistic & P Values \\
\hline Financial Distress $\rightarrow$ Systematic Risk & 2.286 & 0.001 \\
Financial Distress $\rightarrow$ Profitability & 1.813 & 0.010 \\
Systematic Risk $\rightarrow$ Stock Return & 2.753 & 0.006 \\
Profitability $\rightarrow$ Stock Return & 1.986 & 0.030 \\
\hline
\end{tabular}


Hypothesis I tested the relationship between Financial Distress and Systematic Risk, showing the original sample value of 0.221 and $t$-statistic 2.286. The measurement results showed that $t$-statistic $<t$-table (significance level $5 \%=1,66$ ), then the first hypothesis in this study was received. From the data results, it can be interpreted that financial distress independent latent variable sample data proves the relationship with latent variables Intervening (systematic risk), or in other words, X1 provides a significant impact on Z1 with a positive relationship direction. This indicates that the ROA, Debit Payment Ratio and Current Ratio causes systematic risk changes in primary and chemical industry companies. The information presented in the ROA, Debit Payment Ratio and Current Ratio, is quite attractive to investors as a basis for assessing the company's performance. This can be because from the liquidity ratio angle; this ratio provides information related to the fulfilment of its short-term obligations. Still, it is enough to give a positive signal for the continuity of investments invested by investors.

Hypothesis II tests the relationship between Financial Distress and Profitability, showing the original sample value of 0.214 and $t$-statistics of 1.813. The measurement results showed that $t$-statistic $<t$-table (significance level $5 \%=1,66$ ), then the first hypothesis in this study was received. From the data results, it can be interpreted that financial distress independent latent variable sample data proves the relationship with latent variable Intervening (Profitability). In other words, X1 provides a significant impact on Z2 with a positive relationship direction. Any increase or decrease in ROA generated will affect the growth and decline in Stock Return in manufacturing companies. The results of this Analysis indicate that investors also use the profitability ratio of ROA to measure the company's performance in generating profit that will impact the Stock Return to be obtained. In line with some previous research that has been suggested that the greater profitability obtained by the company, the greater the Stock Return received by investors. In this research, financial distress during the pandemic made it very difficult for investors to invest due to the problematic situation in the second quarter of 2020 caused by the instability of the world economy. However, based on the latest considerations from the data presentation, the third and fourth quarter national economic system has been controlled in line with the increasingly controlled pandemic covid outbreak in Indonesia.

Hypothesis III tests the relationship between systematic risk and Stock Return, showing the original sample value of 0.255 and $t$-statistic 1.986. The measurement results showed that $t$-statistic $<t$ - table (significance level 5\%= 1,66), then the first hypothesis in this study was received. From the data results, it can be interpreted that the sample data of independent latent variables of systematic risk proves the relationship with latent variables (Stock Return). In other words, Z1 has a significant impact on Y with a positive relationship direction. Systematic risk occurs as a whole in the market so that all companies will be affected. Rationally when the systematic risk is greater, the sensitivity (sensitivity) of the stock price to the risk in the market higher means that the stock price will increasingly follow (move together) the market index. With the increasing sensitivity of the stock price to the market index, investors are more accessible in predicting the company's share price. The changes in individual and market share prices tend to be the same. The information in the market is more open. Thus the expected Return by investors will be higher.

Hypothesis IV tests the relationship between profitability and Stock Return, showing the original sample value of 0.199 and $t$ statistic 2.273 . The measurement results showed that $t$-statistic $<t$-table (significance level $5 \%=1,66$ ), then the first hypothesis in this study was received. From the data results, it can be interpreted that the sample data of independent latent variables profitability proves the relationship with latent variables (Stock Return). In other words, Z2 gives a significant effect against $\mathrm{Y}$ with a positive relationship direction. i.e. any increase or decrease in ROA generated will impact the increase and decrease in Stock Return in manufacturing companies. The results of this Analysis indicate that investors also use the profitability ratio of ROA to measure the company's performance in generating profit that will impact the Stock Return to be obtained.

\section{Table 2}

Specific Indirect Effect

\begin{tabular}{lcc} 
& T Statistic & P Values \\
\hline Financial Distress $\rightarrow$ Systematic Risk $\rightarrow$ Stock Return & 3.152 & 0.002 \\
Financial Distress $\rightarrow$ Profitability $\rightarrow$ Stock Return & 2.342 & 0.025 \\
\hline
\end{tabular}

Variable relationship through intervening: Financial Distress Systematic Risk $\rightarrow$ Stock Return this indicates $\rightarrow$ that the Return of shares affected by financial distress is mediated with systematic risk, on the increase or decrease in activity will be an influence to Stock Return when the systematic risk increases, then the Stock Return received by investors is low. Systematic risk cannot be avoided but can be minimized with appropriate corporate activities. As an investor can consider before investing in the company, when the condition of systematic Risk increases, it should look at its actions.

Variable relationship through intervening: Financial Distress $\rightarrow$ Profitability $\rightarrow$ Stock Return this indicates that Stock Return influenced by financial distress mediated with profitability, an increase or decrease in growth will affect Stock Return when profitability increases. Investors who want a high return on stocks should calculate the ratio of each company's shares owned, 
especially the percentage of profitability.

\section{Conclusion}

This study concluded that financial distress significantly impacts Stock Return when economic turmoil occurs, especially when there is a pandemic covid-19; this is evidenced by the relationship of variable financial distress with systematic risks of companies that positively impact. Therefore, both cannot be released to support the company's financial stability in the face of national and international economic shocks. The company's profitability is also affected by the validity of the positive value generated from the data on the Indonesia stock exchange. To handle it requires good cooperation from investors and actors of primary and chemical industries. The value resulting from the PLS-SEM Analysis shows that the relationship of four variables shows positive results and are interdependent with each other. Therefore, it is expected that the national economic system is better prepared in the face of global economic shock risks in the future. Investor knowledge is also fundamental in helping the rise of the national economy; it takes good cooperation from all parties for the national economy to continue to grow and develop well.

1. The results of the Analysis of Output Bootstrapping-PLS Financial distress have a significant effect on systematic risk with a p-value of $0.001<0.05$, so it can be concluded that the objectives of this study have been met.

2. The results of the Analysis of Output Bootstrapping-PLS Financial distress have a significant effect on profitability with a pvalue of $0.010<0.05$, so it can be concluded that the objectives of this study have been fulfilled.

3. The Bootstrapping-PLS Output analysis systematic risk results have a significant effect on the Stock Return with a p-value of $0.006<0.05$, so it can be concluded that the objectives of this study have been met.

4. The results of the Analysis of the Output Bootstrapping-PLS Profitability significantly affect the Stock Return with a p-value of $0.030<0.05$, so it can be concluded that the objectives of this study have been fulfilled.

5. The Specific Indirect Effect analysis results also state that Fgan through the systematic risk variable with a p-value of 0.002 $<0.05$, so that financial distress has a significant effect on systematic risk, it can be concluded that the objectives of this study have been met.

6. The results of the Specific Indirect Effect analysis also state that financial distress through the profitability variable with a p-value of $0.025<0.05$. Financial distress has a significant effect on systematic risk. It can be concluded that the objectives of this study have been met.

\section{References}

Arif, D., Yucha, N., Setiawan, S., Oktarina, D., Martah, V., \& Muttaqiin, N. (2020). Applications of Goods Mutation Control Form in Accounting Information System: A Case Study in Sumber Indah Perkasa Manufacturing, Indonesia. The Journal of Asian Finance, Economics and Business, 7(8), 419-424.

Ashraf, B. N. (2020). Stock markets' reaction to COVID-19: Cases or fatalities? Research in International Business and Finance, 54, 101249. https://doi.org/https://doi.org/10.1016/j.ribaf.2020.101249

Barberis, N., \& Huang, M. (2008). Stocks as Lotteries: The Implications of Probability Weighting for Security Prices. American Economic Review, 98(5), 2066-2100. https://doi.org/10.1257/aer.98.5.2066

Barus, M., Sudjana, N., \& Sulasmiyati, S. (2017). PENGGUNAAN RASIO KEUANGAN UNTUK MENGUKUR KINERJA KEUANGAN PERUSAHAAN (Studi pada PT. Astra Otoparts, Tbk dan PT. Goodyer Indonesia, Tbk yang Go Public di Bursa Efek Indonesia). Jurnal Administrasi Bisnis S1 Universitas Brawijaya, 44(1), 154-163.

Benoit, S., Colletaz, G., \& Hurlin, C. (2012). A Theoretical and Empirical Comparison of Systemic Risk Measure: MES Versus Delta Covar. SSRN Electronic Journal. https://doi.org/10.2139/ssrn.2083653

Benoit, S., Colliard, J.-E., Hurlin, C., \& Pérignon, C. (2017). Where the Risks Lie: A Survey on Systemic Risk*. Review of Finance, 21(1), 109-152. https://doi.org/10.1093/rof/rfw026

Bravo-Urquiza, F., \& Moreno-Ureba, E. (2021). Does compliance with corporate governance codes help to mitigate financial distress? Research in International Business and Finance, 55, 101344. https://doi.org/https://doi.org/10.1016/j.ribaf.2020.101344

Chen, J., De Cesari, A., Hill, P., \& Ozkan, N. (2018). Initial compensation contracts for new executives and financial distress risk: An empirical investigation of UK firms. Journal of Corporate Finance, 48, 292-313. https://doi.org/https://doi.org/10.1016/j.jcorpfin.2017.11.002

Cifuentes, R., Ferrucci, G., \& Shin, H. S. (2005). LIQUIDITY RISK AND CONTAGION. Journal of the European Economic Association, 3(2-3), 556-566. https://doi.org/https://doi.org/10.1162/jeea.2005.3.2-3.556

Cont, R., \& Wagalath, L. (2016). FIRE SALES FORENSICS: MEASURING ENDOGENOUS RISK. Mathematical Finance, 26(4), 835-866. https://doi.org/https://doi.org/10.1111/mafi.12071 
Dyah, A. S., \& Mulyo, H. (2012). Analisis Pengaruh ROA, NPM, EPS dan PER Terhadap Return Saham. Ekonomia Dan Bisnis, 210 .

Elyasiani, E., Mester, L. J., \& Pagano, M. S. (2014). Large capital infusions, investor reactions, and the Return and riskperformance of financial institutions over the business cycle. Journal of Financial Stability, 11, 62-81. https://doi.org/https://doi.org/10.1016/j.jfs.2013.11.002

Fich, E. M., \& Slezak, S. L. (2008). Can corporate governance save distressed firms from bankruptcy? An empirical analysis. Review of Quantitative Finance and Accounting, 30(2), 225-251. https://doi.org/10.1007/s11156-007-0048-5

Gilson, S. C. (1989). Management turnover and financial distress. Journal of Financial Economics, 25(2), $241-262$. https://doi.org/https://doi.org/10.1016/0304-405X(89)90083-4

Grice, J. S., \& Dugan, M. T. (2003). RE-ESTIMATIONS OF THE ZMIJEWSKI AND OHLSON BANKRUPTCY PREDICTION MODELS. Advances in Accounting, 20, 77-93. https://doi.org/https://doi.org/10.1016/S08826110(03)20004-3

Hair, J. F., Hult, G. T. M., Ringle, C. M., \& Sarstedt, M. (2013). A Primer on Partial Least Squares Structural Equation Modeling (PLS-SEM). Thousand Oaks. Sage, 165.

Hsu, H.-H., \& Wu, C. Y.-H. (2014). Board composition, grey directors and corporate failure in the UK. The British Accounting Review, 46(3), 215-227. https://doi.org/https://doi.org/10.1016/j.bar.2013.12.002

Li, Z., Crook, J., Andreeva, G., \& Tang, Y. (2020). Predicting the risk of financial distress using corporate governance measures. Pacific-Basin Finance Journal, 101334. https://doi.org/https://doi.org/10.1016/j.pacfin.2020.101334

Mangena, M., Priego, A. M., \& Manzaneque, M. (2020). Bank power, block ownership, boards and financial distress likelihood: An investigation of Spanish listed firms. Journal of Corporate Finance, 64, 101636. https://doi.org/https://doi.org/10.1016/j.jcorpfin.2020.101636

Mitton, T., \& Vorkink, K. (2008). Why Do Firms with Diversification Discounts Have Higher Expected Returns? Journal of Financial and Quantitative Analysis, 45, 1367-1390. https://doi.org/10.2139/ssrn.932960

Nugroho, M., Arif, D., \& Halik, A. (2021). The effect of loan-loss provision, non-performing loans and third-party fund on capital adequacy ratio. Accounting, 7(10), 943-950. https://doi.org/10.5267/j.ac.2021.1.013

Nugroho, M., Halik, A., \& Arif, D. (2020). Effect of CAMELS Ratio on Indonesia Banking Share Prices. The Journal of Asian Finance, Economics and Business, 7(11), 101-106.

Rong, Y., Tian, C., Li, L., \& Zheng, X. (2020). Labour hiring and stock return: A model and new evidence from China. PacificBasin Finance Journal, 59, 101256. https://doi.org/https://doi.org/10.1016/j.pacfin.2019.101256

Salloum, C. C., Azoury, N. M., \& Azzi, T. M. (2013). Board of directors' effects on financial distress evidence of family-owned businesses in Lebanon. International Entrepreneurship and Management Journal, 9(1), 59-75. https://doi.org/10.1007/s11365-011-0209-9

Xu, L. (2021). Stock Return and the COVID-19 pandemic: Evidence from Canada and the US. Finance Research Letters, 38 , 101872. https://doi.org/https://doi.org/10.1016/j.frl.2020.101872

Yucha, N. (2018). Financial Distress, Kinerja Keuangan Dan Manajemen Turnover Perusahaan Publik. ISSN: 2615-6237 Online, 1(1), 30-35.

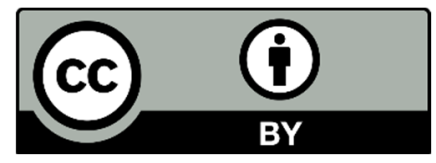

(C) 2021 by the authors; licensee Growing Science, Canada. This is an open access article distributed under the terms and conditions of the Creative Commons Attribution (CC-BY). license (http://creativecommons.org/licenses/by/4.0/). 